\title{
Land in Liberia: The Initial Source of Antagonism Between Freed American Blacks and Indigenous Tribal People Remains the Cause of Intense Disputes
}

\author{
Stephen H. Gobewole ${ }^{1}$ \\ ${ }^{1}$ Walden University, Pawtucket, USA \\ Correspondence: Stephen H. Gobewole, Walden University, 718 Roosevelt Avenue, Pawtucket, RI, 02860, USA. \\ Tel: 401-617-1892. E-mail: sgobewole@cox.net
}

Received: June 6, 2021

doi:10.5539/jpl.v14n4p19
Accepted: June 23, $2021 \quad$ Online Published: June 27, 2021

URL: https://doi.org/10.5539/jpl.v14n4p19

\begin{abstract}
This study examines factors of land grabbing in Liberia, especially from tribal communities, due originally to different social expectations regarding land and contracts between indigenous people and settlers from America. In addition, land appropriation throughout the history of the Liberian nation is due largely to the Americo-Liberian oligarchy and public corruption. The study analyzes survey, empirical, and concession contracts data gathered by the Ministry of Internal Affairs, Sustainable Development Institute, Government of Liberia, Center for Transparency and Accountability in Liberia, and United Nations Mission in Liberia. It then correlates associations between a number of concession companies, their land acreage under operation, county acreage, and incidence of land grabbing to demonstrate an increase in disputes during the early 2000 s due to practices of corrupt public officials. This has resulted from the consistent implementation of inequitable land laws, which have perpetuated land transfer from tribal communities to mostly Americo-Liberian descendants and foreign concessionaires. This land appropriation has fostered public corruption, increased land related disputes, and raised the level of conflict in Liberian society.
\end{abstract}

Keywords: land dispute, tribal community, law, certificate, Liberia, corruption, colonization, conflict

\section{Introduction}

In the early $19^{\text {th }}$ century, freed American black organizations, such as the American Colonization Society and the Maryland State Colonization Society, grabbed indigenous tribal communities' land, notably from the Dei, Bassa, $\mathrm{Kru}$, Grebo, and Gola people, to establish their own country, Liberia, on the West Coast of Africa (the sub-region). The initiative was accomplished under the disguise of legitimate land transactions (purchases, agreements, treaties, etc.), but these were not legal, because some tribal chiefs were not aware that their agreement with freed American blacks entailed the selling of their homeland. Berkeley (2001) stated that, "The first deed of settlement [in 1821] was secured, at gunpoint, in return for three hundred dollars' worth of muskets, beads, tobacco, gunpowder, clothing, mirrors, food and rum, from a chief named 'King Peter,' who reportedly came only later to understand the full implications of the term "sale" (p. 29). This transaction and subsequent similar transactions were inconsistent with the local African tradition and culture of communal land protocols. As a result, the sub-region's (today's Liberia) tribal communities were engaged in persistent resistance against the freed American blacks, Americo-Liberians, well into the $20^{\text {th }}$ century.

This behavior continued with the Americo-Liberian oligarchy, descendants of freed American blacks, codifying biased land laws like the Liberian Code of Laws of 1956 (even though the practice existed well before 1956) that empowered them to transfer more tribal communities' land as private property for themselves, their friends, their families, and to foreign concessionaires to accumulate wealth. This system has developed corrupt land authorities (land commissioners, land surveyors, tribal chiefs, magistrates, etc.), increased fraudulent land transactions (sales, purchases, leases, rents, etc.), enhanced duplication of single parcel documents (deeds, titles, tribal certificates, cornerstones, etc.), and led to proliferation of property (land) value misrepresentation on the market. The result is an increase in land related disputes among citizens and concessionaires, while creating difficulty in assessing accurate valuation of land parcels in Liberia, destabilizing the economy.

As a result of this long history of land appropriation and economic destabilization, the Land Rights Law of 2018 
addresses tribal communities' land ownership rights. However, it does not address fraudulent land transactions and public officials' corruption. This is the underpinning to most land disputes and land market dysfunction in the Liberian economy throughout the entire history of the nation. Therefore, the Liberian Congress needs to enact legislation that protects citizens' property rights. This will improve the property (land parcel) valuation assessment system and enhance the courts' ability to enforce contracts in the country.

\section{Literature Review}

The land conflicts that exist in Liberia today are a result of Americo-Liberians in search of a homeland and the simultaneous European quest for natural resources. The Europeans began arriving on the African continent in the $15^{\text {th }}$ century to extract gold in West Africa, specifically in today's Ghana. The period was marked by a huge fortress on the African coast, which was built to temporarily store and protect the mineral before shipping it to Europe (Gobewole, 2018a; Stride \& Ifeca, 1971). Gobewole (2018a) stated that "In 1482, the Portuguese built Elmina Castle on the coast of modern Ghana. The first of many fortified dungeons, the local ruler, Kwame Ansa, initially opposed the building" (p. 18). This situation, enabled by Portuguese gold prospectors, created instability in the region. Therefore, tribal communities had to be resettled to make way for European miners.

The intrusion compelled indigenous communities to move in every direction and further into the tropical rain forest of the sub-region, an area that includes today's Liberia. This new location was difficult for communities used to subsistence farming, since the perpetual rainfall in the sub-region makes the soil type lateritic, creating leaching when it rains and forming into hardpan when the weather dries up (Sawyer, 1992). However, indigenous tribal communities were constrained by the extension of a commercial network from Western Sudanic traders and European colonialists seeking to extract resources (Gobewole, 2018a; Liebenow, 1987). The communities' problems were worsened by difficulty in farming with manual tools (cutlass, hoe, axe, knife, etc.) for subsistence.

The displacement of tribal communities from their original villages and towns was just the start of trouble with farm lands. The tribal ethnic groups, Mande, Mel, and Kruan speaking peoples, again encountered the American Colonization Society and the Maryland State Colonization Society (another group of freed American blacks) in the early $19^{\text {th }}$ century in search of a country of their own. The problem is there was no available land in the subregion to build a nation for freed American blacks. DiDomenico (2014) stated that "The settlers did not arrive on uninhabited land, but rather land occupied by communities governed by kinship and common ancestry. Land was held by native Africans based on a socio-spatial organization, meaning each community or village possessed its own discreet land or territory and protected its own domain from raids and intruders" (p. 3). However, the freed American Blacks were determined to create a nation at the expense of indigenous tribal communities on the Grain Coast of West Africa.

\subsection{The American Colonization Society}

In an effort to accomplish this objective, Dr. Eli Ayres, the American Colonization Society agent, and Lieutenant Robert Stockton, Captain of the U.S.S. Alligator, engaged in a confusing land transaction with Zolu Duma, alias King Peter, a tribal community chief. Lieutenant Stockton ensured that the deal was consummated by pressuring the tribal chiefs to sign a contract (with a scratched mark). Gobewole (2016b) stated that "The negotiation for the purchase of land between freed American blacks (Americo-Liberians) and native tribes was advanced when Lieutenant Stockton put a pistol to Zolu Duma's head, which forced him and other native chiefs to sign the 1821 land contract" (Liebenow, 1987; Pham, 2004) (pp. 73-74), an event that occurred on Cape Mesurado (current day Monrovia, Liberia) on December 15, 1821 (Gobewole, 2016b). Upon realization of the American Colonization Society representatives' intent to acquire his tribe's land, Zolu Duma, also known as King Peter, "returned the initial payment (gifts), refused the balance due payment, asked the free blacks to leave, and organized a native resistance against the colonists" (Pham, 2004). Johnson (1987) stated that "The agents of the colonists believed that they had bought a strip of the Grain Coast [today's Liberia] and had the deed to it in the paper on which the chiefs had scratched a mark; the chiefs did not know that they were selling the country on which they had lived from the earliest memory of the tribe" (p. 44). The acquisition of indigenous tribal communities' land by the American Colonization Society (freed American blacks), and its successful establishment of a settlement at Cape Mesurado (today's Monrovia), encouraged other freed American blacks to make the venture. The Maryland State Colonization Society repeated the same process with a slightly different land agreement in 1834 at Cape Palmas in the Grebo tribal community section of the sub-region, which is approximately 250 miles southeast of Cape Mesurado.

\subsection{The Maryland State Colonization Society}

In 1834 further in the southeast, President John Latrobe of the Maryland State Colonization Society (MSCS) purchased tracts of land from the Grebo (specifically, the Nyomowe tribe) chiefs near Cape Palmas to establish 
the Colony of Maryland in Africa (Sawyer, 1992). This land deal was different from Dr. Eli Ayres' at Cape Mesurado for a few reasons. First, the Grebo (Nyomowe) chiefs had extensive experience working with European merchants; second, the chiefs were seeking a defense pact with the settlers against the Kudemowe (a rival tribe); and third, they were interested in trade expansion with the freed American blacks and educational advancement for their peoples (Martin, 1968; Sawyer, 1992). The treaty indicated that land was ceded specifically for those two latter purposes. However, this land agreement was modified at least twelve times between 1834 and 1849, which substantially increased the Cape Palmas Colony land possession to accommodate more freed American blacks, a situation that led to the MSCS's "subjugation of the Grebo communities to colonial laws" (Martin, 1968; Sawyer, 1992). Sawyer (1992) stated that "New arrivals required the establishment of new settler communities. The desire to maintain settler communities in close proximity to each other led to a reversal of policy: Grebo political communities were require to leave their towns and villages in the region of the cape" (p. 86). The tribal communities immediately responded in 1837 by imposing a ban on commercial activities, which resulted in higher commodity (palm oil, rice, etc.) prices for the settlers (Martin, 1968; Sawyer, 1992). Unfortunately, the removal of tribal communities from their homelands to grab land for private and commercial ownership in Liberia would become a common practice by Americo-Liberians. The indigenous Grebo tribal chiefs did not realize that their experience of a temporary agreement with European traders would not be replicated in deals with freed American blacks. Sawyer described the relationship regarding land transactions between tribal community chiefs and freed American blacks as follows:

Operating within a completely different cultural frame, indigenous rulers engaged in land transactions on the basis of traditional tenancy principles under which land was used by "strangers" but never totally alienated from the indigenous "masters of the land." It was to become clear that the Liberian colonial authorities were far different from European traders and that their presence in the subregion and their claim to land were permanent - even if these had to be enforced by the sustained use of military power (Sawyer, 1992, pp. 87-88)

It is critical to understand that land grabbing for establishing settlements or colonies was not limited to the American Colonization Society and the Maryland State Colonization Society. Instead, the practice was common among freed American blacks, slave states in the United States, and plantation owners following the American Civil War. The sub-region of West Africa was occupied by several organizations, known as colonization societies, financed by slave states in the United States. The Library of Congress's documentation of Liberia's historical time described the situation as follows:

Slave states in North America, increasingly interested in getting rid of their free African-American populations, encouraged the formation of colonization societies. These groups organized themselves independently of the ACS [American Colonization Society] and founded their own colonies in Liberia for transplanting free African-Americans. Some of the "volunteers" were emancipated only if they agreed to emigrate. The Maryland State Colonization Society established its colony in Cape Palmas, Liberia. Virginia and Mississippi also established Liberian colonies for former slaves and free blacks (Library of Congress, 2021, 1820 to 1847).

These colonization societies were all in pursuit of land to establish their own colonies, which created demand for indigenous tribal communities' land. This need for land resulted in perpetual conflict between freed American blacks and tribal peoples. Moreover, the settlers completely disregarded the communal land ownership system practiced by the native tribes and instituted new laws for land tenure, a complexity that underpins most of the land disputes in Liberian society today. Liebenow (1969) stated that "In the long run the greatest economic irritant may still be the initial source of antagonism between the founding settlers and the indigenous tribal leaders: land" (p. 209).

The colonization period (1820 to 1847) ended with most of the sub-region (today's Liberia)--in other words, tribal people's homelands--being "claimed as owned" by freed American blacks. From the Cestos River in the southwest (approximately River Cess County), known by the natives as Nibue or Nuan, to Cape Mount County in the southeast, most of Liberia's costal land mass was claimed by the Virginia, Mississippi, and Pennsylvania colonies. The rest of the country's costal area (further southwest of the Cestos River) was claimed by the Maryland colony. 


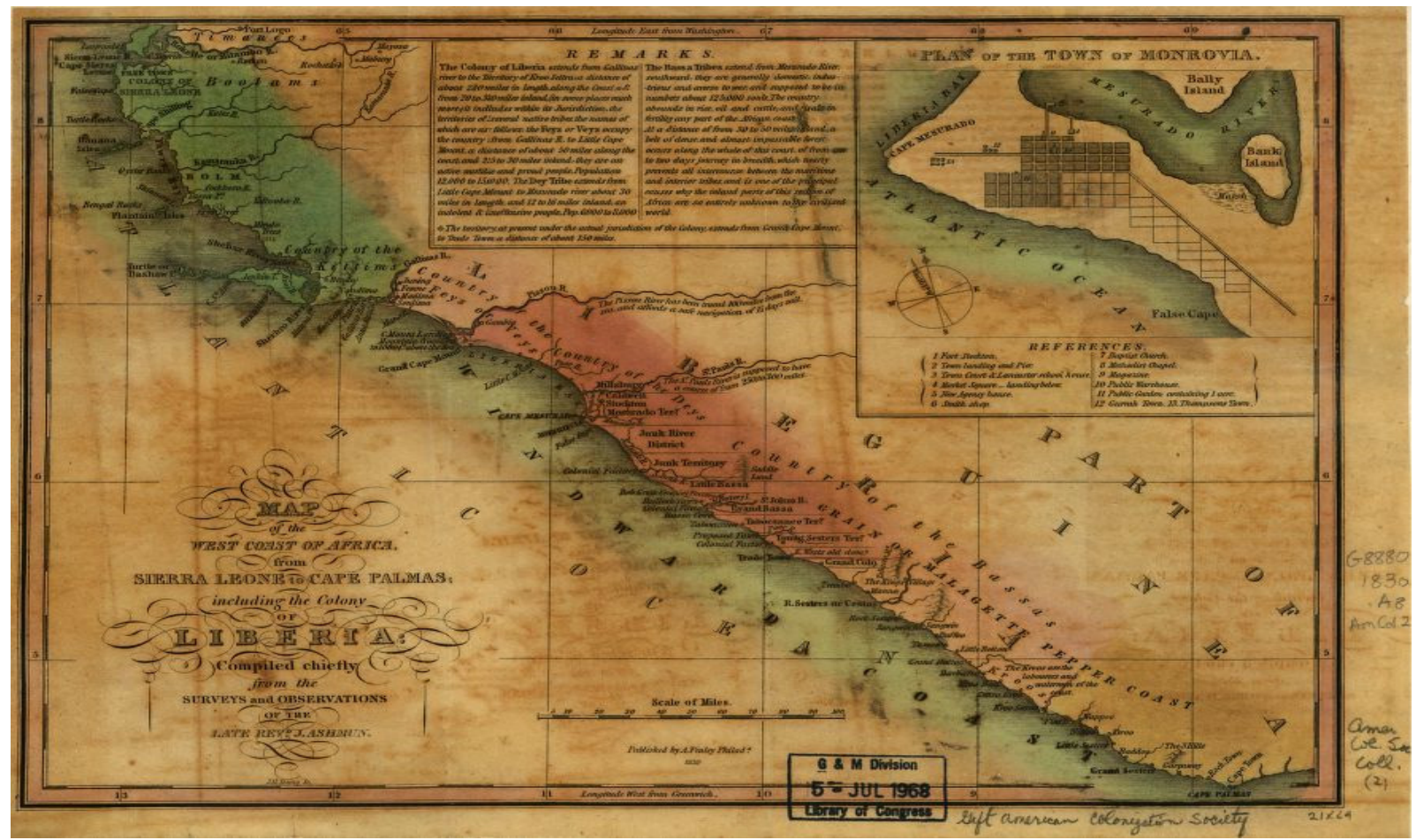

Figure 1. Map of the West Coast of Africa in 1830

Note. Library of Congress

The Library of Congress's documentation of Liberia's historical time described the situation as follows:

The colonies established by the Virginia Colonization Society, the Quaker Young Men's Colonization Society of Pennsylvania, and the American Colonization Society merged as the Commonwealth of Liberia and claimed control over all settlement between Cestos River and Cape Mount. The Commonwealth adopted a new constitution and a newly-appointed governor in 1839 (Library of Congress, 2021, 1820 to 1847).

This situation placed tribal communities along the coast, including the Vai, Dei, Bassa, Kru, and Grebo, practically at risk of losing their ancestral land. Therefore, they were compelled to resist the freed American blacks' dominion. Gobewole (2016b) stated that "This was the beginning of the resistance of many native tribes, and it illustrates their concern about the free American blacks who were taking and keeping their land. But it was to no avail, because the U.S. and Britain [international organizations] assisted the Americo-Liberians" (p. 68).

These facts partly explained why the United States delayed its recognition of Liberia's independence for 15 years, from the country's founding in 1847 until February 5, 1862, even though the United States Congress appropriated a hundred thousand dollars to purchase land and other commodities for the American Colonization Society's endeavor to found a country for freed American blacks in Africa (Liebenow, 1987). Moreover, "[T]he U.S. government steadfastly refused to recognize the purchased areas as an official American colony, which created many international problems for the Colonization Society, the Americo-Liberian settlers, and the American government itself" (Liebenow, 1987). Chin and Finkelman (2021) stated that

Under the Slave Trade Act of 1819, Congress authorized that illegally trafficked slaves be sent, at government expense, to Africa, after 1822 to a settlement created in Liberia, operated by a private organization with extensive governmental connections, the American Colonization Society ("ACS")... Members [the ACS], at various times, included several presidents and future presidents [of the United States], including James Madison, James Monroe, Andrew Jackson, John Tyler, Millard Fillmore, and Abraham Lincoln (pp. 15 and 45).

As a result, the international community, most importantly Britain, France, and Germany, made no effort to ensure equity for the tribal peoples in adherence to their tradition on land usage. Liebenow (1969) stated that "Generally, diplomats in international quarters did not question the legal right of Liberian chiefs to sell land held in communal 
trust any more than they did the right of chiefs to do so elsewhere in Africa" (p. 18). The reason is that most of the confiscation of tribal people's land benefited colonization efforts by Britain, France, Belgium, Holland, and others.

\subsection{Resistance to Land Grabbing}

The tribal communities in the sub-region (today's Liberia) continuously resisted and waged war against freed American blacks for grabbing or confiscating their land. Gobewole (2016b) described the resistance by indigenous tribal peoples in his book Liberia's Political Economy:

Their tribal ancestors went to war with the settlers, complained to Liberia's government, and appealed to the ACS for protection to no avail. As a result, the Americo-Liberian settlers illegitimately occupied tribal land for approximately a century and the half. This is partly responsible for the territorial division and why Americo-Liberians ended up with smaller sections (Gobewole, 2016b, p. 153).

This effort persisted well into the $20^{\text {th }}$ century. Table 1 reveals that in $1822,1839,1854,1875$, and 1915 , tribal chiefs-initiated resistance to oppose freed American blacks from grabbing their land. These efforts were all defeated because U.S. naval forces repeatedly secured victory for the Americo-Liberians.

Table 1. Tribal Communities Resistance to Freed American Blacks Land Confiscation in Liberia

\begin{tabular}{|c|c|c|c|}
\hline year & Tribal Groups & Land Agreements & Resolution \\
\hline 1822 & $\begin{array}{l}\text { Bassa, Dey, and Gola chiefs Todo Konk, } \\
\text { Bromley, and headed by Zolu Duma alias } \\
\text { King Peter }\end{array}$ & $\begin{array}{l}\text { The Doukor Contract in } 1821 \\
\text { between the American } \\
\text { Colonization Society's agent Dr. } \\
\text { Eli Ayres, U.S.S. Alligator's } \\
\text { Captain Lieutenant Robert } \\
\text { Stockton and Tribal chiefs }\end{array}$ & $\begin{array}{l}\text { The U.S. naval vessel Cyane Secured } \\
\text { victory for the freed American blacks }\end{array}$ \\
\hline 1837 & $\begin{array}{l}\text { The Grebo tribal communities (Nyomowe, } \\
\text { Kudemowe, etc.) }\end{array}$ & $\begin{array}{l}\text { The Land Treaty of } 1834 \text { between } \\
\text { the Maryland State Colonization } \\
\text { Society's president John Latrobe } \\
\text { and Grebo Chiefs }\end{array}$ & $\begin{array}{l}\text { The Grebo tribal communities imposed } \\
\text { a trade embargo on palm oil, rice, and } \\
\text { other agriculture commodities }\end{array}$ \\
\hline 1854 & The Grebo and Kru tribal peoples & $\begin{array}{l}\text { The Land Treaty of } 1834 \text { between } \\
\text { the Maryland State Colonization } \\
\text { Society's president John Latrobe } \\
\text { and Grebo Chiefs }\end{array}$ & $\begin{array}{l}\text { The U.S. naval vessel John Adams and } \\
\text { militiamen from Liberia secured } \\
\text { victory for the independent State of } \\
\text { Maryland. As a result, in } 1857 \\
\text { Maryland become a county of Liberia }\end{array}$ \\
\hline 1875 & The Grebo Confederation & $\begin{array}{l}\text { The Land Treaty of } 1834 \text { between } \\
\text { the Maryland State Colonization } \\
\text { Society's president John Latrobe } \\
\text { and Grebo Chiefs }\end{array}$ & $\begin{array}{l}\text { The U.S. naval vessel Alaska assisted } \\
\text { the Americo-Liberian government in } \\
\text { achieving military victory against the } \\
\text { Grebo chieftains }\end{array}$ \\
\hline 1915 & $\begin{array}{l}\text { The Kru tribal communities on the Sinoe } \\
\text { and Bassa coast }\end{array}$ & $\begin{array}{l}\text { Freed American blacks arbitrarily } \\
\text { reversing land treaties and policies } \\
\text { and confiscating more Kru tribal } \\
\text { communities' land to maintain } \\
\text { settlers in closed proximity }\end{array}$ & $\begin{array}{l}\text { The U.S. naval vessel Chester supplied } \\
\text { ammunition to the Americo-Liberian } \\
\text { government, which helped it in } \\
\text { achieving victory against the Kru } \\
\text { peoples }\end{array}$ \\
\hline
\end{tabular}

Note. Berkeley, B. (2001). Johnson, C. S. (1987). Liebenow, J. G. (1987). Liebenow, J. G. (1969). Pham, J. (2004). Sawyer, A. (1992).

This chronology of indigenous tribal communities' (and their chiefs') resistance to Americo-Liberians occupying their land reveals that the sub-region was mostly engulfed with land conflict between the early $19^{\text {th }}$ and $20^{\text {th }}$ 
centuries. Harris (2012) stated that, "for the first 80 years the relationship might be described as competitive and conflictual rather than colonial" (p. 44). The system was created and exacerbated by unfair land laws (policies, codes, regulations, etc.) instituted by the Americo-Liberian oligarchy in Liberia's early years (Gobewole, 2016b). Johnson (1987) stated that "The ineffectiveness and the ethno-racism of Americo-Liberian rulers was so great that native tribes rebelled periodically and, in some cases, even wished to have rulers of European descent. Their rebellious spirits were met with Americo-Liberian hostility, sometimes backed by U.S. assistance" (p. iii).

\subsection{The Republic of Liberia}

After the establishment of a state in 1847, the Americo-Liberian oligarchy begun to institute laws to legitimize the appropriation and ownership of more and more tribal communities' land in the hinterland. This was accomplished by transferring "[T]he land of tribal communities into public land, [to] purchase those properties as private land in deed tenure" (Gobewole, 2016b). The initial Liberian law, in the mid 1800s, was designed to disenfranchise tribal people and their descendants by appropriating more of their ancestral land to Americo-Liberians and their descendants. In the beginning, indigenous tribal people's descendants in the hinterland governed their communities and managed their land and resources, up to the mid 1920s. The enactment of the Hinterland Land Law in 1923 minimized that authority by mandating the "[G]overnment to administer tribal affairs through chiefs who shall govern freely according to tribal customs and traditions so long as they were not contrary to law" (DiDomenico, 2014, p.4). This transformation of the customary system was due to the Americo-Liberian oligarchy's awareness of natural resources inherited in tribal communities' land. Siakor (2012) stated that "The fragility of rural tenure security in Liberia has been compounded by contradictory national land and natural resources policies, ambiguous legal frameworks, weak implementation, low professional and resource capacity, corruption, and a lack of political will to ensure tenure security for rural communities" (p. 19).

The Americo-Liberian oligarchy began modifying land laws in 1847 to grab tribal land for governmental and personal benefits. This process resulted in large tracts of customary land transferred to concessionaires and Americo-Liberian citizens. For example, "The Barclay, Tubman, and Tolbert administrations took advantage of the law and transferred thousands of acres of tribal land to families, friends, and supporters, as well as renting them to concession companies for mining, rubber production, and timber harvesting to acquire personal wealth" (Gobewole, 2016b; Liebenow, 1969; Sawyer, 1992). The land law that most disenfranchised tribal people's descendants took shape in the Liberian Code of Laws of 1956. This legislation empowered Liberia's presidents, all Americo-Liberians, to appropriate all tribal communities' land in the country. Amos Sawyer described the law and its function in his book, The Emergence of Autocracy in Liberia:

The Liberian Code of Laws specifies that "each tribe is entitled to the use of as much of public land in the area inhabited by it as is required for farming and other enterprises essential to tribal necessities. It shall have the right to possession of such land as against any person whomsoever" (RL, Liberian code 1956, 1, chap. 11, sec. 270:60 [author's emphasis]). Although the law holds out the possibility of "possession," indigenous societies are not automatically granted ownership to the land they long occupied (Sawyer, 1992, p. 242).

This statute also made it impossible for tribal people and their offspring to financially benefit (sell, rent, farm, etc.) from their community's land. In addition, the law gave "Liberia's presidents, all Americo-Liberians [during the First Republic], authority to take tribal land as they saw fit" (Gobewole, 2016b). This allowed them to retitle, resell, and give tribal communities' land "to concession companies, including Firestone, Semi Darby, Salala Rubber Corporation, and Sinoe Rubber Corporation, denied tribal people an ability to cultivate cash crops, such as oranges, pineapples, bananas, cocoa, and coffee" (Gobewole, 2016b). As a result, large tracts of tribal communities' land were acquired by the Americo-Liberians and concession companies. More important, the Liberian government, headed by Americo-Liberians and later, some tribal Liberians, disregarded tribal peoples and their descendants' dependence on their land, their primary asset, for social and economic activities like "hunting, fishing, farming, and its forest for performing cultural rituals and making tools" (Gobewole, 2018b). This situation has continuously increased tension, even into the 21st century, for land ownership between indigenous tribal people's descendants and Americo-Liberians, encompassing most contemporary Liberian citizens (Gobewole, 2016b; Harris, 2012; Pham, 2004). In other words, confiscation that occurred from the very beginning of Americo-Liberian settlement largely underpins land conflicts or disputes in Liberian society today. Silas Kpanan'Ayoung Siakor discussed the dilemma of current land disputes cause by concession companies in his article "Uncertain Futures."

The contract obliges the government to allocate land free of encumbrances to Sime Darby [a Palm Oil concessionaire]. This is impossible: there is no land free of encumbrances in the counties targeted for the development. In addition, some contractual provisions requiring joint implementation have either been 
ignored or poorly executed; and the company planned and implemented its activities poorly from the onset.... Both the government and Sime Darby must take steps to proactively address some of the potential sources of conflict with communities in areas where the company plans to expand. This may require significant changes to the contract, the mode of implementation of the contract, and the company's behavior (Siakor, 2012, p. 9).

The World Bank acknowledged the problematic basis of land ownership by indicating that "Today, most Liberians may be only dimly aware of the political heritage of the ACS [American Colonization Society], but they still live with its institutional consequences, namely a dualistic land-tenure system" (World Bank, 2005). This underlying system still exists today and largely exacerbates land conflict in the Liberian nation.

\section{Methodology}

This study uses data compiled by Silas Kpanan'Ayoung Siakor (Sustainable Development Institute and World Rainforest Movement), the Government of the Republic of Liberia, Edward Mulbah and John R. Dennis (Liberia Peace Building Office at the Ministry of Internal Affairs, United Nations Mission in Liberia, United Nations Development Programme, and African Centre for the Constructive Resolutions of Disputes), Gerald D. Yeakula and Shine G. Williams (Center for Transparency and Accountability in Liberia), Jessica Vapnek, Alfred Fofie, and Peter Boaz (University of California-Hastings College of the Law and ClArb evolving to resolve), Stephen H. Gobewole (Liberia's Political Economy), and the United States Library of Congress. This information has been used to measure correlations between indicators of agreements, land-property disputes, land border-boundary disputes, public corruption, and fraudulent activities in land transactions, while documenting the Liberian government's conflict (dispute) resolution capacity. This analysis also allows the study to reveal rising tension in land-related conflict in Liberian society. As a suggested remedy, the enactment of legislation to improve property rights for citizens is essential to reduce public corruption, which will decrease land disputes in Liberian society. The data collected has been used to create charts and tables to assist readers to better understand land disputes, public corruption, and increased tension in land conflict phenomena covered by the study.

\section{Unequal Land Regime}

The nation's prior dualistic land-tenure system created opportunities for the Americo-Liberian oligarchy and its government to benefit immensely at the expense of tribal communities' impoverishment. This was accomplished because "The code of [land] law made it illegal for indigenous (tribal) people to sell, rent, or acquire economic benefit from their land while giving Liberia's presidents, all Americo-Liberians, authority to appropriate tribal land as they saw fit" (Gobewole, 2016b). For example, in the late $20^{\text {th }}$ century "The Barclay, Tubman, and Tolbert administrations took advantage of the law and transferred thousands of acres of tribal land to families, friends, and supporters, as well as renting them to concession companies for mining, rubber production, and timber harvesting to acquire personal wealth" (Gobewole, 2016b; Liebenow, 1969; Sawyer, 1992). After 197 years, the Weah administration attempted to correct this inequity arising from grabbing tribal communities' land. On September 19, 2018, the Land Rights Law was signed into law by President George Weah to give complete ownership, rights, and control to tribal communities over their ancestral lands.

The Land Rights Law of 2018 gives tribal communities ownership of their lands, authority to negotiate concession agreements, and rights to financially benefit from their ancestral lands. These rights were previously denied to tribal communities under the Liberian Code of Laws of 1956. However, the Land Rights Law of 2018 fails to protect tribal individuals' personal ownership rights and prevent tribal land certificate fraud, perpetuating corrupt practices by land authorities. These failures make Liberia's lands improperly documented, mispresented, and missassessed by the land market (De Soto, 2000). Moreover, this situation facilitates duplication of land markers (cornerstones), single parcels' multiple sales, and inaccurate land values. Gobewole (2016b) stated that "This phenomenon was exacerbated by Liberia's weak property laws, which transferred the land of tribal communities to Americo-Liberians and made their assets "extralegal" and economically invisible... This situation continues even today" (p. 63).

Table 2 describes that basic language of Liberia's land law (Title 1, Chapter 11), which formalized what had been occurring over the previous century or more, from its institution by President King with minor revisions in 1956 under President Tubman and 1973 under President Tolbert, which was finally repealed under President Weah in 2018. The Tenure Facility (2012) indicates that "Conflict over land and resources in Liberia is rooted in the emigration of former slaves from North America, known as 'settlers', who formed an independent country in 1847. Their descendants failed to recognize the customary rights of Indigenous Peoples in law and allocated immense contracts for natural resource exploitation on their ancestral land" (p. 1). 
Table 2. Legislative transformation of authority over Liberian code of laws in Title 1, Chapter 11

\begin{tabular}{|c|c|c|}
\hline Year & Leadership & Customary Land Law and Language \\
\hline 1821-Early 1900s & $\begin{array}{l}\text { Agents of the colonization societies and } \\
\text { earlier Presidents (from Joseph J. Roberts } \\
\text { in } 1847 \text { to Daniel E. Howard in 1920) }\end{array}$ & $\begin{array}{l}\text { The American Colonization Society, the Maryland State } \\
\text { Colonization Society, the Virginia Colonization Society, } \\
\text { and the Quaker Young Men's Colonization Society of } \\
\text { Pennsylvania, settled freed American blacks in the sub- } \\
\text { region (today's Liberia) on West Africa. The Freed } \\
\text { American blacks (Americo-Liberians) established } \\
\text { Liberia but confined their rule mainly to the coastal areas } \\
\text { and left the inland areas (hinterland) to indigenous } \\
\text { Liberians (tribal groups) to administer based on } \\
\text { customary principles. }\end{array}$ \\
\hline 1923 & President Charles D. B. King & $\begin{array}{l}\text { The Americo-Liberian Oligarchy acknowledged tribal } \\
\text { communities land ownership based on customary } \\
\text { boundaries and subject land administration governance to } \\
\text { customary paradigms. But the Hinterland Land Law } \\
\text { mandated compliance with government administration of } \\
\text { tribal affairs. }\end{array}$ \\
\hline 1949 & President William V. S. Tubman & $\begin{array}{l}\text { The Liberian Code of Law, Article 66, mandated that the } \\
\text { right and title of the respective tribes to lands of an } \\
\text { adequate area for farming and other enterprises essential } \\
\text { to the necessities of the tribe remain inherent in the tribe } \\
\text { to be utilized by them for these purposes; and whether or } \\
\text { not they have procured deeds from Government } \\
\text { delimitating by metes and bounds such reserves, their } \\
\text { rights and interest in and to such areas are a perfect } \\
\text { reserve and give them title to the land against any person } \\
\text { or persons whosoever. }\end{array}$ \\
\hline 1956 & President William V. S. Tubman & $\begin{array}{l}\text { The Liberian Code of Laws specifies that "each tribe is } \\
\text { entitled to the use of as much of public land in the area } \\
\text { inhabited by it as is required for farming and other } \\
\text { enterprises essential to tribal necessities. It shall have the } \\
\text { right to possession of such land as against any person } \\
\text { whomsoever" (RL, Liberian code 1956, 1, chap. 11, sec. } \\
270: 60 \text { [author emphasis]). Although the law holds out } \\
\text { the possibility of "possession," indigenous societies are } \\
\text { not automatically granted ownership to the land they long } \\
\text { occupied (Sawyer, 1992, p. 242). }\end{array}$ \\
\hline
\end{tabular}


Note. Liberian Code of Laws of 1956. Sawyer, A. (1992). The Land Rights Law of 2018. DiDomenico, L. N. (2014).

The new law requires that tribal communities, administered by the Community Land Development and Management Committee, have ownership rights to their ancestral land (The Land Rights Law, 2018). Basically, the act addresses the underpinning of long existing land tension between descendants of Americo-Liberians and indigenous tribal peoples in Liberian society. It also attempts to provide resolution to potential disputes about current land contracts, agreements, and private deed arrangement made by the Liberian government. The Land Rights Law addresses private ownership and concessionary contracts as follow:

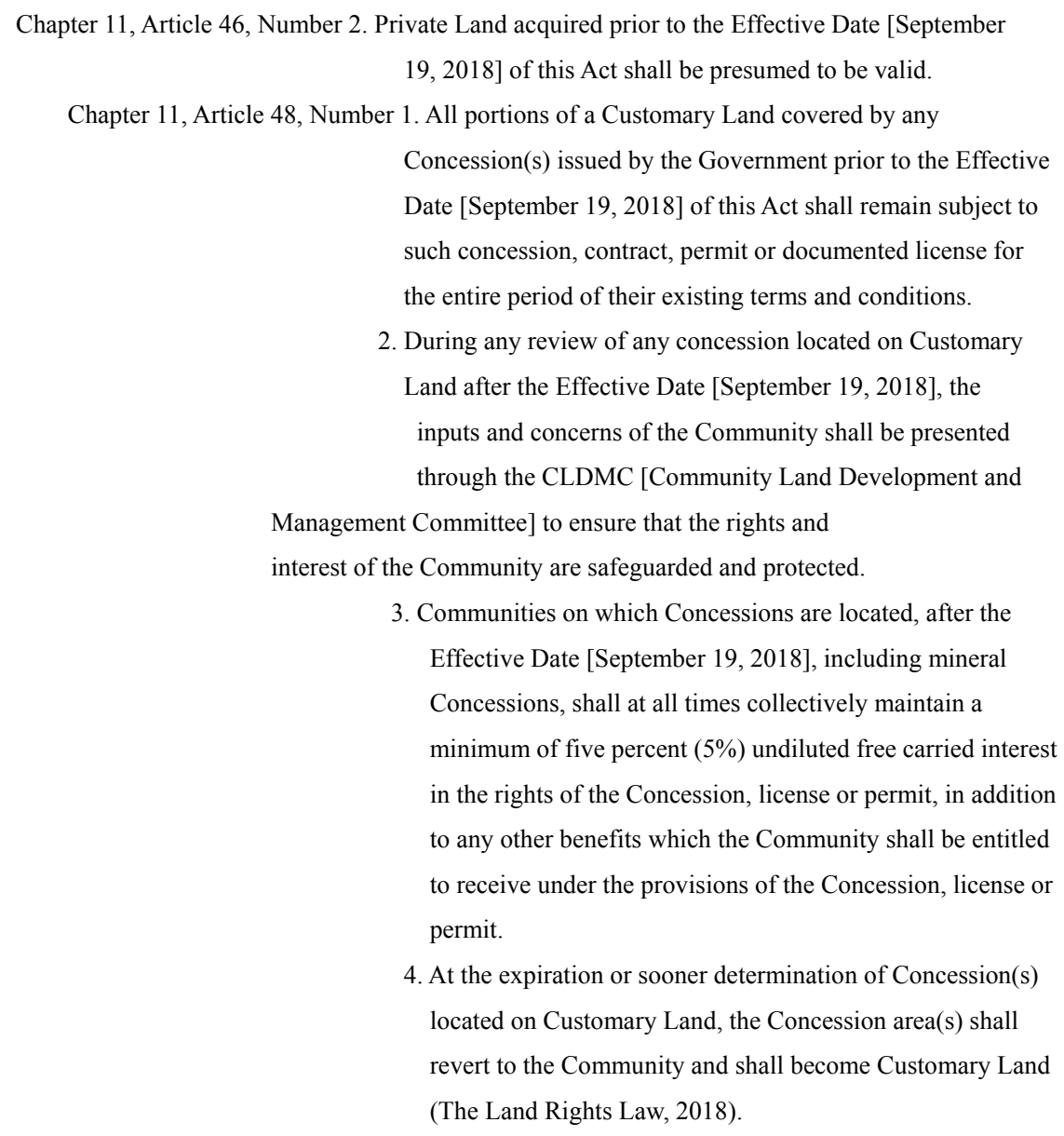

The lack of such a land rights act in the past has denied financial benefits to tribal people's descendants and created perpetual poverty in tribal communities around the country. Foreign companies had been free to exploit resources without compensating tribal communities. This includes Bomi County with the Liberia Mining Company, Margibi County with the Firestone Plantation Company, Nimba County with the Liberian American Swedish Minerals Company, and Bong County with the Bong Mining Company. Gobewole (2016b) discussed the adverse effects of 
this economic policy in Liberia's Political Economy:

This approach [concession agreements] has allowed foreign companies to extract Liberia's natural resources at discount prices due to low wages, tax breaks, favorable land tenure, etc., without requirements for infrastructure, such as all-weather roads, communication networks, and utility facilities, as well as community education development. Foreign investors are able to achieve such bargain concession contracts because the government officials negotiating these agreements are usually seeking their own private gain. For example, they are focused on acquiring ownership (shares) in the concession companies, taking bribes from the foreign investors, and securing employment for relatives, compromising the citizens, the tribal communities, and the nation's interest (Gobewole, 2016b, p. 89).

The exploitation of indigenous people's land has enriched individual Americo-Liberians, but left the original inhabitants impoverished. Even though The Land Rights Law of 2018 revised the original inequity of tribal people's land ownership rights, it is simply the first step in a positive direction.

Such a law is helping to right the extremely long tenure of current concession agreements, which is partly the source of disputes in tribal communities. The government not only gave out these extensive concessionary contracts to the Firestone Plantation Company--for one million acres of tribal people's land for 99 years--in the $20^{\text {th }}$ century, but such practices continue "today with companies like Sinar Mas (owner of Golden Veroleum Liberia that signed a 65 years agreement in 2010), Sime Darby (a Malaysian company that signed a 63-year agreement in 2009), ArcelorMittal mining in northern Nimba County, and Putu Iron Ore Mining Corporation in southern Grand Gedeh County" (Gobewole, 2016b). Therefore, the approach will alleviate long existing injustice about land and potential conflict, because tribal communities will now have "Community Land Development Management Committees" to negotiate land agreements and administer land activities for their villages, towns, and clans.

\section{Data Analysis and Finding}

The Land Rights Law of 2018 immediately gives formal land rights to a large percent of the population, indigenous tribal people's descendants. After all, the Liberian government maintains multiple agreements with concessionaries for a large quantity of the country's land. Giahyue (2018) stated that "The topic has been contentious since most of the population has no formal rights to their land, and the state has signed away more than 40 percent of national territory in concessions for logging, mining, and agriculture, according to rights groups" (p. 1). However, it is yet to be seem how the government can successfully implement this new land law with fraudulent documents (deeds, titles, tribal certificates, etc.) and corrupt land authorities (surveyors, tribal chiefs, land commissioners, etc.).

Chart 1 reveals that of Liberia's total land mass, $15 \%$ is allocated among logging concessions, $15 \%$ among agricultural concessions, $15 \%$ among mining concessions, and the remaining $60 \%$ among the general population. Concessionaires are in custody of two-fifths of Liberia' territory, representing a significant amount of national assets (land and citizenry) to hand over to foreign investors' control. 


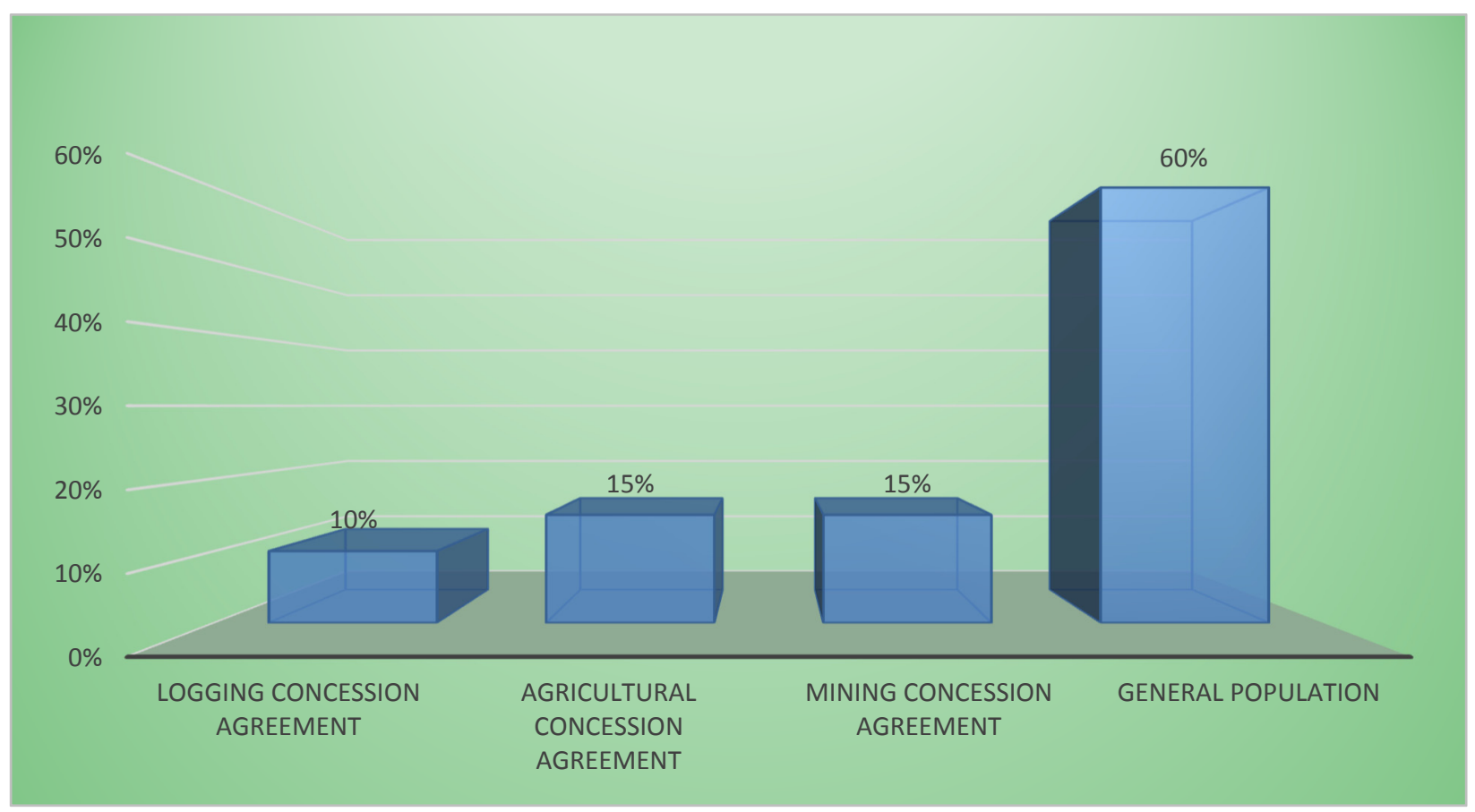

Figure 2. Liberia land allocation in 2012

Note. Giahyue, J. (2018). Siakor, S. K. (2012).

On the individual (citizen) level, the practice of illegally acquiring other people's land in Liberia is a deeply rooted public policy problem. This issue is exacerbated by the method of land ownership in Liberia today, which lacks a detailed legal record. A statistical record of authority or control of land in Liberia reveals that "One-third of those with access to land indicated that they had only a verbal agreement or nothing as means to prove their rights to the land they use. Two-thirds had some written record, including a land deed (41\%), tribal certificate (16\%), or lease agreement (8\%)" (Patrick Vinck, Phuong Pham, and Tino Kreutzer, 2011, p. 47). This situation results from fraud and corrupt practices in land transactions.

The reasons for land disputes in Liberia include government contracts with concessionaires, public officials' acceptance of bribes (corruption) for illegal land transactions, and land authorities' (the president, tribal chiefs, surveyors, land commissioners, etc.) lack of sufficiently detailed written information (boundaries, borders, original deeds, cornerstone markers, etc.) about land parcels being sold or purchased. Yeakula \& Williams discussed potential illegal activities in land transaction in their article "Land and Corruption Report Liberia."

The public Land Sale procedure lends itself to corruption by the President signing all deeds. This act creates room for manifestations of patronage, clientelism, favoritism, etc. By giving the President such power, citizens run the risk of not buying public land if the President does not desire to sell to a particular individual. It also means that the President can sell public land to whomsoever she/he pleases (Yeakula et. al., 2018, p. 10).

Table 3 indicate concession companies that have more than twenty-five years of contractual agreement with Liberia's government and counties where they function. It reveals that Firestone Plantation Company, Liberia Agricultural Company, Equatorial Palm Oil, Sime Darby Plantation-Liberia, Golden Veroleum Liberia, and Forest Management Contract-Areas (A, K, I, P, and F) operate in two or more countries. In addition, Firestone Plantation Company, Sinoe Rubber Plantation, and Forest Management Contract-Areas (B and C) control 38\%, 24\%, and 20\% of tribal communities land in Grand Bassa and Margibi, Sinoe, and River Cess Counties respectively. Stated differently, Firestone Plantation Company $(1,000,000$ acres $)$ has authority over more land than political subdivisions like Bomi County (480,000 acres), Grand Kru County (962,560 acres), Margibi County (646,400 acres), Maryland County (567,680 acres), and Montserrado County (471,680 acres). In addition, River Cess, Sinoe, Grand Bassa, and Grand Gedeh Counties' tribal peoples are the most land deprived, with multiple concession operations of five, four, three, and three respectively. 
Table 3. Agricultural and timber concession companies with twenty-five plus years contract in Liberia

\begin{tabular}{|c|c|c|c|c|}
\hline Company & County & $\begin{array}{l}\text { Concession- } \\
\text { Land Acreage }\end{array}$ & $\begin{array}{l}\text { County-Land } \\
\text { Acreage }\end{array}$ & $\begin{array}{l}\text { Concession- } \\
\text { Land Acre } \\
\text { Percent of } \\
\text { County-Land } \\
\text { Acreage }\end{array}$ \\
\hline Firestone Plantation Company & Grand Bassa and Margibi & $1,000,000$ & $2,607,360$ & $38 \%$ \\
\hline Liberia Agricultural Company & Grand Bassa and River Cess & 299,998 & $3,343,360$ & $9 \%$ \\
\hline Sinoe Rubber Plantation & Sinoe & 599,999 & $2,505,600$ & $24 \%$ \\
\hline Equatorial Palm Oil & Grand Bassa and Sinoe & 168,998 & $4,466,560$ & $4 \%$ \\
\hline Salala Rubber Company & Bong & 99,999 & $2,167,680$ & $5 \%$ \\
\hline Sime Darby Plantation-Liberia & $\begin{array}{l}\text { Bomi, Bong, Grand Cape Mount, } \\
\text { and Gbarpolu }\end{array}$ & 768,960 & $6,317,440$ & $12 \%$ \\
\hline Golden Veroleum Liberia & $\begin{array}{l}\text { Grand Kru, Maryland, River Cess, } \\
\text { and Sinoe }\end{array}$ & 864,869 & $5,418,240$ & $16 \%$ \\
\hline Forest Management Contract-Area A & Gbarpolu and Lofa & 294,648 & $4,860,800$ & $6 \%$ \\
\hline Forest Management Contract-Area B & River Cess & 141,497 & $1,382,400$ & $10 \%$ \\
\hline Forest Management Contract-Area C & River Cess & 146,716 & $1,382,400$ & $10 \%$ \\
\hline Forest Management Contract-Area K & $\begin{array}{l}\text { Grand Gedeh, Nimba, and River } \\
\text { Cess }\end{array}$ & 657,770 & $6,827,520$ & $10 \%$ \\
\hline Forest Management Contract-Area I & Grand Gedeh and Sinoe & 324,860 & $5,096,320$ & $6 \%$ \\
\hline Forest Management Contract-Area P & Grand Kru and Maryland & 294,905 & $1,530,240$ & $19 \%$ \\
\hline Forest Management Contract-Area F & Grand Gedeh and River Gee & 629,088 & $3,854,080$ & $16 \%$ \\
\hline
\end{tabular}

Note. Siakor, S. K. (2012). Government of the Republic of Liberia. (2008).

The amount of land under control of external corporations is striking and threatens sovereignty. For example, Firestone Plantation Company with a million acres and a ninety-nine year contractual duration is a district (political subdivision) in Margibi County. Overall, an estimate of "[L]and allocated to rubber, oil palm, and logging concessions covers approximately $2,546,406$ ha or approximately $25 \%$ of the country" (Siakor, 2012, p. 17). In other words, these concessionaires have control over and access to millions of acres of tribal communities and their land that could be used for subsistence, cultural rituals, and commercial farming, a situation that has increased tension, conflict, and land disputes across the country. Simply put, entities like Firestone Plantation Company have enormous political power in Liberia's governmental system. Therefore, the Liberian Congress needs to renegotiate its concession agreements, reallocate its land ownership (tribal communities, shareholders, the government of Liberia, etc.), reduce its contractual term (number of years), and substantially minimize its political authority.

Due to the long-term influence of concessionaires, hundreds of thousands of acres of originally indigenous land remain contested. Table 4 reveals that River Cess County, Margibi County, Firestone District, and Montserrado County have populations of $65,862,199,689,61,988$, and $1,144,806$, which are mostly affected by land-property disputes, land-property disputes and public corruption, land-property disputes and public corruption, and public corruption and land-property disputes, respectively. 
Table 4. The political subdivisions most affected by land related conflicts in Liberia in 2017

\begin{tabular}{ccc}
\hline County/District & Population in Area & Root Causes of Conflict \\
\hline River Cess County & 65,862 & Land-Property Disputes \\
Firestone District & 61,988 & Land-Property Disputes and Public Corruption \\
Margibi County & 199,689 & Land-Property Disputes and Public Corruption \\
Montserrado County & $1,144,806$ & Public Corruption and Land-Property Disputes \\
\hline
\end{tabular}

Note. Mulbah, E. \& Dennis, J. R. (2017). Government of the Republic of Liberia. (2008).

Silas Kpanan'Ayoung Siakor explained the unpredictable situation tribal communities are encountering in his article "Uncertain Futures."

The situation facing communities impacted by the expansion of Sime Darby's Plantation in Liberia is dire. The oil palm plantation is on their doorsteps, and their farms and farmlands are being swallowed up by it. Most men and women in the affected villages are now out of work, and their children are hungry. There are very few alternative livelihood options. All of the locals interviewed for this report said no compensation had been paid to them for land taken over by the company (Siakor, 2012, p. 9).

Similar problems face indigenous communities in counties throughout Liberia. Such an enormous power over a large population of disfranchised citizens and corrupt activities is largely responsible for Liberia's high number of land disputes. Ponsford (2016) stated that "An estimated 90 percent of Liberia's civil court cases are related to land and as many as 63 percent of violent conflicts in Liberia have their root in land rights issues" (p. 2). This land dispute crisis is a potent threat (tribal riots, individual resistance, civil war, etc.) to the national peace (Truth and Reconciliation Commission of Liberia, 2009).

Chart 2 reveals that root causes of conflict, like Land Border-Boundary disputes, Land-Property Disputes, and Public Corruption Issues, are at $22.8 \%, 57.8 \%$, and $40.0 \%$ respectively in Liberian society. These numbers add up to approximately $120 \%$ because there is some overlap. The Land Border-Boundary and Land-Property Disputes' high rates indicates that access to land is critical for citizens of tribal communities to maintain their livelihood. Siakor (2012) stated that "[T]he challenges faced by people living in areas already being cultivated for oil palm [by Sime Darby's plantation] are manifold: they have lost their farms, their lands, and various livelihood options, and some of their culturally significant sites have been destroyed" (p. 9). This demand for scarce land resources in concessionary areas (usually a single county with multiple companies) and corrupt public officials administering land transactions has led to these high levels of disputes. 


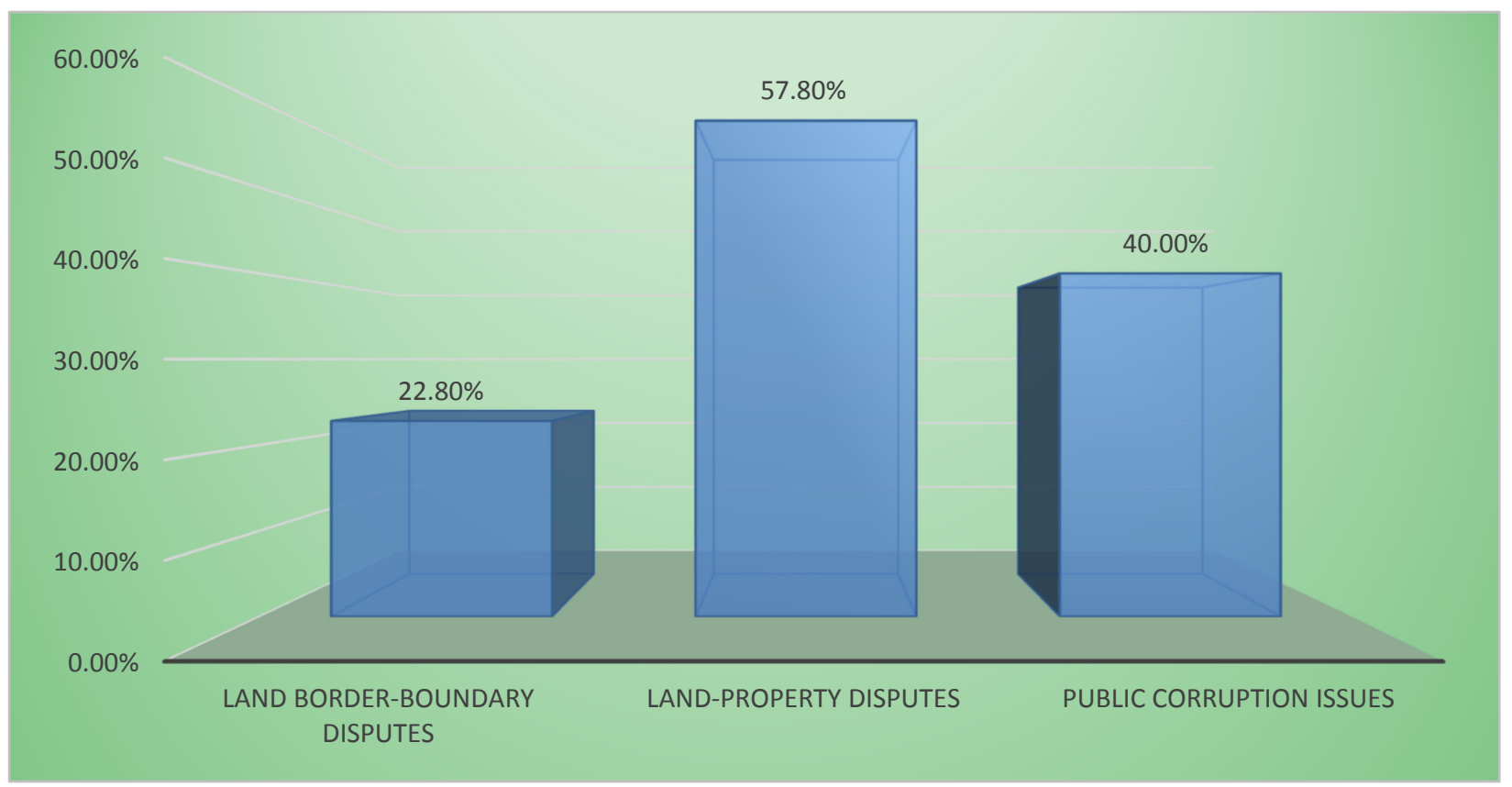

Figure 3. The percentages of root causes of conflict in Liberia in 2017

Note. Mulbah, E. \& Dennis, J. R. (2017).

These high rates of disputes and corrupt activities underscore the 1,268 cases of multiple sales of the same parcel reported to the Liberia's Land Authority between July 2015 and June 2019 (Kamara, 2020). The land sales are usually illegitimate because surveyors and land commissioners are ignorant of accurate lot size or parcel borders and boundaries. This lack of knowledge results in a single parcel being sold to multiple purchasers, which increases the potential for disputes.

\section{Public Corruption and Land Disputes}

The issue of land dispute in Liberia has long been exacerbated by public officials, notably surveyors, land commissioners, and magistrates, accepting bribes to survey, register, or record land titles and deeds for sales and purchases (sometimes verified or unverified). It is common knowledge among citizens that "Bribery is present at all levels including magistrate and circuit courts" and that "Land Commissioners who handle community land disputes usually take bribes to complicate the process by forwarding cases to court" (Yeakula and Williams, 2018, p.70). These corrupt transactions are proceeding even when original or primary land deeds do not exist in the national archives. Thomson Reuters (2015) stated that “After years of conflict. Liberia's land management is in a state of disarray. Land records are missing, difficult to search for or at risk of deteriorating... In 2010, just over 700 deeds were registered among its 3.8 million people" (p. 2). This makes it impossible to determine land ownership and makes corruption much easier. To complicate matters, most deeds went missing during the Civil War (1989 to 2003). Yeakula et al. (2018) stated that "Resurveying of the land is important to establish how much of the land on the 'mother deed' is still covered by the title." However, "Land owners engaged in multiple sale of land usually change surveyors in order to resell land. Unlike the initial surveyor, the new surveyor may have limited or no knowledge on the history of ownership of the parcel and may, therefore, sanction the sale" (Yeakula et al., 2018, p. 71). Liberia's system, reaching back to the country's historical roots, has enhanced land conflicts.

As a result, the essential disputes in Liberia in the past decade were mostly about land. DiDomenico (2014) stated that "Even the Liberian Supreme Court recognizes the increasing violence and instability resulting from land disputes" (p. 3). A population-based survey (Talking Peace) conducted by Patrick Vinck, Phuong Pham, and Tino Kreutzer revealed that citizens' complaints centered on farm land-grabbing, land boundary issues, and land inheritance problems. The report discussed the difficulties encountered by Liberia's judicial institutions in resolving land disputes. Vinck et al. (2011) stated that "While over four out of five non-land disputes experienced since the war had been resolved (83\%), just half the farm land-grabbing cases had been solved (53\%), and about two-thirds of land disputes over boundaries or inheritance had been resolved (respectively $64 \%$ and $66 \%$ of the disputes)" (p. 61). Land disputes remain at the center of disputes in Liberia, and create a dangerous instability. 
The situation has only been getting worse. Chart 3 reveals that land related conflicts in Liberia in 1981 to 1985 , 1991 to 1996,2004 to 2005 , and 2006 to 2015 were on average $1.6 \%, 2.6 \%, 6.5 \%$, and $46.9 \%$ respectively. This dramatic recent increase indicates a rising trend in conflict among citizens for access and control of land, a phenomenon that requires attention from the Liberian government:

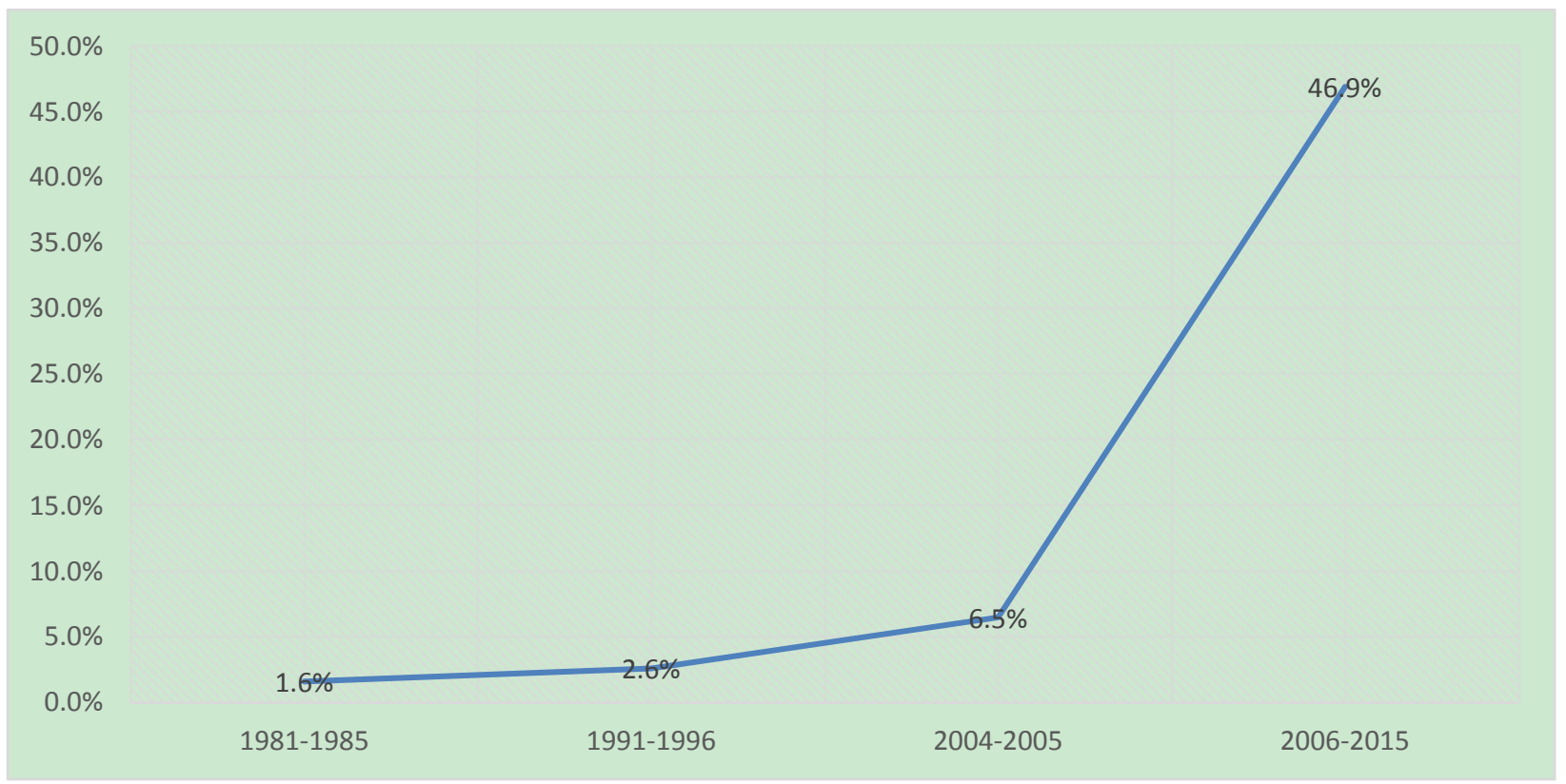

Figure 4. The levels of land related conflict in Liberia between 1981 and 2015

Note. Mulbah, E. \& Dennis, J. R. (2017).

The issue of corruption and inaccurate transaction permeates land acquisition by facilitating double sales of the same lots, impersonation of land ownership, multiple deeds issued for a single lot, and illegal registration of land titles. Gerald D. Yeakula and Shine G. Williams (2018) discussed the corrupt practices of government officials when implementing land transaction: "Land is a public interest issue, which can be subsumed under corruption offenses as it relates to the conduct of public officials taking bribes, falsifying land documents and using their official positions to amass land or influence land deals" (p. 38).

This corruption has made Liberians lose confidence in their land institutions (title, deed, cornerstone, etc.) and authorities (surveyors, land commissioners, magistrates, etc.). On the other hand, the Liberian public has developed trust in their tribal authorities, including village, town, and paramount chiefs, to mediate land transactions and arbitrate land disputes (Vinck et al., 2011).

\section{Resolution of Land Disputes}

Survey results for resolving land disputes in Liberian society showed that tribal authorities, mainly village and town chiefs, are more successful than governmental authorities, magistrate and circuit courts. The population found the informal system trustworthy, accessible, and easy to use in the resolution of their land disputes. Vinck et. al. (2011) explained "[T] he prominent role of village and town chiefs in resolving land-related disputes: $39 \%$ of those who had experienced land-grabbing since the war had consulted village or town chiefs to resolve the dispute. Among those who experienced disputes over land boundaries or land inheritance dispute, the proportions were 24\% and 32\%, respectively" (p. 61). A majority of Liberia's population lives in rural and tribal communities where the central government has minimum representation. In those areas, the tribal chiefs (village, town, paramount, and sectional) are the primary governing authorities that provide critical public administration. This makes it essential for them to be included in mitigating and resolving land disputes or conflicts in Liberian society and suggests that tribal authorities should be incorporated in the government's judicial (not just local) structure with paid staff and public facilities. Such an approach will assist government in effectively resolving land issues.

Currently, the attempts used to resolve land-related disputes in Liberia include reallocation of political subdivisions and governmental initiatives, by the United States and Liberia, such as Mitigating Land Dispute. The reallocation of counties is a strategy tribal people's descendant have used to combat land injustice and reacquire their ancestral 
land, which is by redesigning political divisions (counties). This process (tribal people's descendents' redesigning of counties in the 1980s) has allowed the Grebo, Kru, Bassa, Kpelle, and Dey ethnic groups to reclaim land from Americo-Liberians' original settlements. Gobewole discussed the reforming of political subdivisions based on tribal people's descendants' land rights in Liberia:

The territorial boundaries have continued to change throughout Liberia's history. For example, changes in the boundaries of Montserrado, Grand Bassa, Sinoe, and Maryland counties can be attributed to descendants of Dei, Bassa, Kru, and Grebo native tribes reacquiring land illegally taken by AmericoLiberians in the 19th and 20th centuries. Montserrado County went from 2,497 to 737 square miles; Grand Bassa County went from 5,224 to 3,064 square miles; and Maryland County went from 2,391 to 887 square miles. These changes have resulted in Liberia currently having 15 counties and a more tribally segregated citizenry (Gobewole, 2016b, p. 152-153).

The enactment of The Land Rights Law of 2018 is a good effort by government to restore

tribal people's land rights following historical inequities. However, the current land market is plagued with missing and fraudulent documents, which is perpetuating corruption in land transactions. Moreover, if some land has been returned to indigenous people's new counties, in other cases, original counties land has been taken away by the Americo-Liberians. Therefore, a new law is needed to mitigate land related disputes in the country.

Table 5 reveals that Montserrado County had a square mileage of 2,497 in 1839, but only 735 in 1985; Margibi County with 1,010 square miles was reduced in 1984; Bomi County with 750 square miles was reduced in 1985, which left the county with 737 square miles today; Grand Bassa County had 5,224 square miles in 1839; River Cess County with 2,160 square miles was reduced in 1985 leaving it with 3,064 square miles; and Maryland County had 2,391 square miles in 1857; and Grand Kru County with 1,504 was reduced in 1984 leaving it with 887 square miles. This practice has resulted in the original counties (freed American blacks descendants' territories) ending up with smaller political subdivisions in the country (Gobewole, 2016b). This dynamic is changing the economic and political balance in favor of tribal people's descendants.

Table 5. Transformation of Liberia political subdivision between 1847 and 1985

\begin{tabular}{|c|c|c|c|}
\hline Original County & New County & Year Founded & Square Mileage \\
\hline \multirow[t]{4}{*}{ Montserrado } & & 1839 & 2,497 Beginning \\
\hline & Margibi & 1984 & $-1,010$ \\
\hline & Bomi & 1985 & -750 \\
\hline & & & 737 Today \\
\hline \multirow[t]{3}{*}{ Grand Bassa } & & 1839 & 5,224 Beginning \\
\hline & River Cess & 1985 & $-2,160$ \\
\hline & & & 3,064 Today \\
\hline \multirow[t]{3}{*}{ Maryland } & & 1857 & 2,391 Beginning \\
\hline & Grand Kru & 1984 & $-1,504$ \\
\hline & & & 887 Today \\
\hline
\end{tabular}

Note. Gobewole, S.H. (2016b). Government of the Republic of Liberia. (2008).

These activities in Table 5 are clarified for readers with maps in Figure 2, which shows changes in the sizes of Liberia's original counties, including Maryland County, which joined the nation in 1857 . The maps reflect creation of new political subdivisions for tribal groups (basically transferred territories' land), while showing a reduction in areas settled by freed American blacks (Gobewole, 2016b), primarily, the coastal area from Cape Muserado (in Montserrado County) to Cape Palmas (in Maryland County). Intriguingly, "Evidence of Liberia's American roots are pervasive all along the coast, from Robertsport to Maryland County. Quaint echoes of the antebellum South can be found amid the crumbling, mildewy street" (Berkeley, 2001). In other words, the American influence pervades a region primarily occupied by people indigenous to the area. 


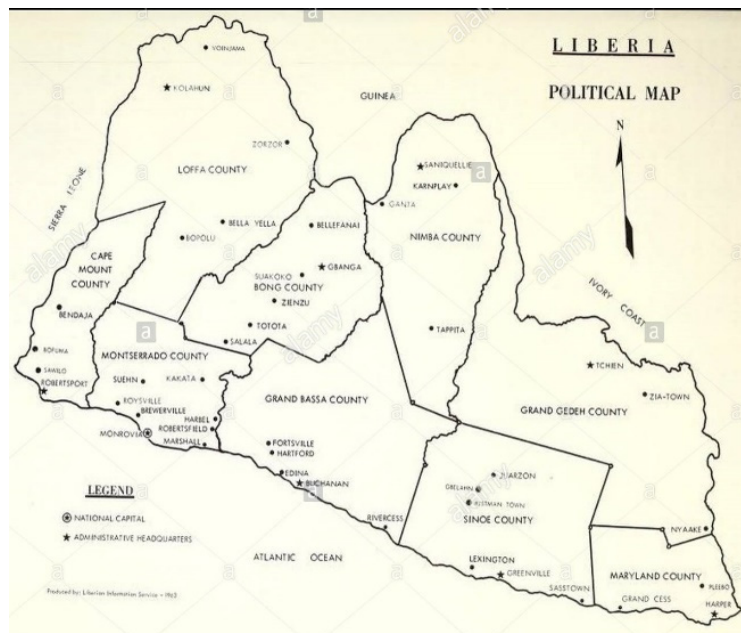

a alamy stock photo

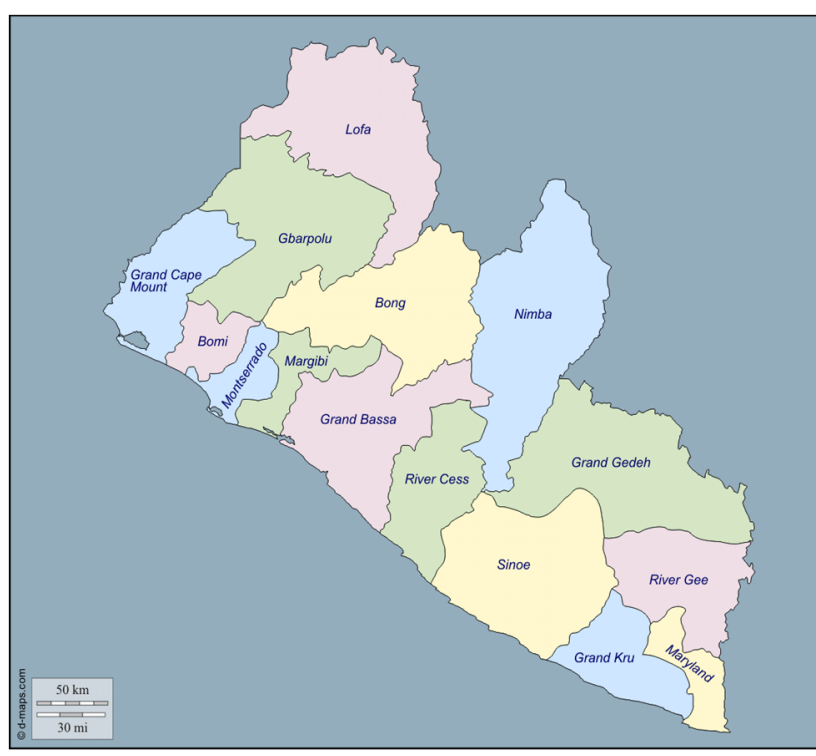

Figure 5. Map of Liberia in 1964 and 1985

Note. A Alamy Stock Photo and D-Maps.Com

To avoid conflict, violence, and insecurity in tribal communities, the Mitigating Land Dispute in Liberia Project, launched in 2011, applied an "early warning/early response system" to defuse potential disagreements in land negotiations (Vapnek, Fofie, and Boaz, 2017). The strategy ensures "[T] hat the dispute resolution framework is drawn from the local culture [which] also leads to its acceptability" (Vapnek et. al., 2017). This community-based approach enhanced the project's ability to prevent disputes from escalating into full-bloom conflict. Vapnek et. al. (2017) stated that "An emphasis on community participation, local ownership, local leadership and capacity building has earned the MLDL [Mitigating Land Dispute in Liberia] project a position of trust in resolving disputes in rural [tribal] communities and conveying security concerns up and down the chain from local to regional to national and back again" (p. 300).

However, these measures do not effectively address Liberia's land related dispute epidemic, because they do not focus on property rights protection. Gobewole discussed the issue of property rights:

The current policy for protecting property rights in Liberia is so weak that individuals use squatting tenure or illegal purchase as reasons for establishing ownership for a house, a land or a farm lot. Unfortunately, those forms of ownership minimize their ability to leverage the property in a capitalist economy, because there is no title or contract for courts to enforce an agreement (Gobewole, 2016b, p. 118).

Therefore, the Liberian Congress needs to enact new legislation to improve the gap of individual property rights protection and duplication of land documents in "The Land Rights Law, 2018." This will assist citizens to efficiently conduct land transaction in the country.

\section{Conclusion}

If there were ever land agreements between freed American blacks and indigenous tribal communities, they were certain to be flawed, "because the parties had different concepts of land ownership...the basis of native ownership is communal; in contrast, that of European culture is individualistic" (Gobewole, 2016b; Johnson, 1987). As a result, according to Liebenow (1987), "The settlers and their agent did not appreciate that the concept of 'sale' of land had no meaning in societies where land was distributed communally on the basis of usufructuary right of occupancy rather than individual private freehold" (p. 16). Put in context, land in traditional societies in the subregion (today's Liberia) served a critical function, which is far more than financial transactions (selling and buying) of positional goods or assets. In other words, for tribal peoples, "land was the basic fabric in their existence. Land was the bond linking the ancestors with the present and the future. Association with it defined the community and legitimized its institutions" (Sawyer, 1992). However, the financier of this initiative, the United States, had a much different issue to contend with than indigenous tribal people's land rights.

As indicated above, the nation got its initial lands in disputed transactions from Cape Mesurado to Cape Palmas between freed American blacks and indigenous tribal chiefs. This continued once Liberia was founded, when the 
freed American blacks, or the Americo-Liberian oligarchy, instituted a dualist tenure system (land policies) that assisted them in continuously confiscating tribal communities' land. This system was, at least partly, the reason for Liberia's civil war in 1989, periodic conflicts over the years, and a system that has presently developed into individuals squatting on and grabbing other people's land. The current regime needs further reform to minimize disputes that threaten another civil war.

The fraudulent land titles, deeds, and cornerstones created by corrupt public officials misrepresent the authenticity of the land. This distortion of public corruption will transition into the land assessment (worth) assigned by the market. Yeakula et al., (2018) stated that "The official price for a parcel of public land is so low. The different between the official price and the actual, market value of a parcel of public land represents an opportunity for corruption of the public land sale process. These low prices create room for officials to extort money or request bribes from buyers" (p. 10). In other words, the title or deed will not indicate an accurate representation of the land value (price) for consumers. Such a deficiency is equivalent to not having a land documentation (title, deed, etc.) at all, which has negative effects in a market economy (De Soto, 2000).

This demonstrates that, despite the passage of the Land Rights Law of 2018, there are still adverse implications from the Liberian Code of Laws of 1956, a legacy that is currently producing land disputes due to improper documentation of land ownership in the country. These issues make it difficult for Liberia's political and economic systems to progress from poor, to emerge, and to develop a functional democratic capitalism. To overcome these barriers, Liberia needs quality individual property (land) ownership regulation that must be effectively enforced for the public welfare without the interference of corrupt or patronage activities in land transactions. Such a system will ensure accuracy in land valuation and instill citizen confidence in land transactions in Liberian society, a critical factor for an efficient capitalist economy. This will also help to improve the weak private sector of Liberia's economy.

Therefore, the Liberian Congress needs to enact additional legislation to renegotiate some of the existing concession contracts, licenses, and permits. In addition, the government should conduct an audit of existing lands held under tribal certificates. This examination will identify an inventory of legitimate and illegitimate land titles with tribal certificates. Such action will prevent the transformation of fraudulently documented land into deeded land. This is essential because most tribal certificates were issued illegally by tribal chiefs uninformed about land parcel, border, boundaries, and other aspects of the Western legal system. Without additional reforms beyond the 2018 legislation, Liberian society will only face a weak economy and continued civil strife.

\section{References}

Berkeley, B. (2001). The graves are not yet full: Race, tribe and power in the heart of Africa. New York, NY: Basic Books. https://doi.org/10.1215/07402775-2001-2008

Chin, G. J., \& Finkelman, P. (2021). Birthright citizenship, slave trade legislation, and the origins of federal immigration regulation. Retrieved from http://www.papers.ssrn.com/sol3/Data_Integrity_Notice.cfm?abid=3822658

De Soto, H. (2000). The mystery of capital: Why capitalism triumphs in the West and fails everywhere else. New York, NY: Basic Books.

DiDomenico, L. N. (2014). Land disputes unearth shaky legal foundation: will Liberia's land reform provide stability? Retrieved from http://www.faoa.org

Giahyue, J. (2018). Liberia passes landmark law to secure ancestral land rights. Retrieved from https://www.reuters.com/article/us-liberia-landrights-lawmaking/liberia-passes-landmark-law-to-secureancestral-land-rights-iduskcn $1 \mathrm{~m} 02 \mathrm{fg}$

Gobewole, S. H. (2016). Liberia's political economy: An examination of public institutional quality (rule of law, democratic accountability, and state authority) based on citizens' ethnic, residence, and gender status. Indianapolis, IN: Dog Ear Publishing.

Gobewole, S. H. (2018a). Continental impoverishment: The effect of extractive institutions (Resource Extraction, Neoliberal Policies, and Patrimonial Governance) in African Nations and a policy for Economic Development. Indianapolis, IN: Dog Ear Publishing.

Gobewole, S. H. (2018b). Naturalization: the case for constitutional reform to extend citizenship to immigrant in Liberia. Retrieved from https://www.pdf.semanticscholar.org

Government of the Republic of Liberia. (2008). National population and housing census. Retrieved from http://www.emansion.gov.ir/doc/census_2008provisionalresults.pdf 
Harris, D. (2012). Civil war and democracy in West Africa: Conflict resolution, elections and justice in Sierra Leone and Liberia. New York, NY: Tauris. https://doi.org/10.5040/9780755619054

Johnson, C. S. (1987). Bitter Canaan: The story of the negro republic. New Brunswick, NJ: Transaction Books.

Kamara, V. (2020). Liberia: more cases of multiple sales of land despite law. Retrieved from $\mathrm{https}$ //frontpageafricaonline.com/news/liberia-more-cases-of-multiple-sales-of-land-despite-law/

Liberian Code of Laws. (1956). Adopted the legislature of the Republic of Liberia. Retrieved from https://hydrastg.library.cornell.edu

Library of Congress. (2021). History of Liberia: a time line. Retrieved from https://www.loc.gov/collections/mapsof-liberia-1830-to-1870/articles-and-essays/history-of-liberia/1820-to-1847/

Library of Congress. (2021). Map of the West Coast of Africa: from Sierra Leone to Cap Palmas. Retrieved from https://www.loc.gov

Liebenow, J. G. (1969). Liberia: The evolution of privilege. London, England: Cornell University Press.

Liebenow, J. G. (1987). Liberia: The quest for democracy. Bloomington, IN: Indiana University Press.

Map of Liberia. Retrieved from https://www.alamy.com and https://www.d-maps.com

Martin, J. J. (1968). The dual legacy: government authority and mission influence among the Glebo of Eastern Liberia, 1834-1910. Ph.D. diss., Department of History, Boston University.

Mulbah, E., \& Dennis, J. R. (2017). Mapping opportunities for the consolidation of peace in Liberia: "Voices from the countryside." Retrieved from https://reliefweb.int

Pham, J. (2004). Liberia: Portrait of a failed state. New York, NY: Reed Press.

Rodrik, D. (2007). One economics many recipes: Globalization, institutions, and economic growth. Princeton, NJ: Princeton University Press. https://doi.org/10.1515/9781400829354

Sawyer, A. (1992). The emergence of autocracy in Liberia: Tragedy and challenge. San Francisco, CA: ICS Press.

Siakor, S. K. (2012). Uncertain futures: the impacts of Sime Darby on communities in Liberia. Retrieved from http://www.wrm.org.uy

Stride, G. T., \& Ifeca, C. (1971). People and empires of West Africa: West Africa in history, 1000-1800. London, UK: Thomas Nelson \& Sons Ltd.

The Land Rights Law of 2018. An act to establish the land rights law of 2018, Republic of Liberia. Retrieved from https://iredd-lr.org

The Tenure Facility. (2021). Overview Liberia: land rights law creates opportunities to grant title to those who live on customary land. Retrieved from https://thetenurefaciliy.org/timeline/liberia/

Thomson Reuters. (2015). Through war and peace, Liberia's land legacy. Retrieved from https://tax.thomsonreuters.com

Truth and Reconciliation Commission of Liberia. (2009). TRC final report released. Retrieved from http://trcofliberia.org/

Vinck, P., Pham, P., \& Kreutzer, T. (2011). Talking peace: A population-based survey on attitudes about security, dispute resolution, and post-conflict reconstruction in Liberia, Human Rights Center, University of California, Berkeley - School of Law. https://doi.org/10.2139/ssrn.1874025

World Bank. (2005). Community cohesion in Liberia: A post-war rapid social assessment. Retrieved from $\mathrm{https} / / /$ scholar.google.com/scholar?q=community+cohesion+in+Liberia\&btnG $=\& h l=e n \& a s \_s d t=0 \% 2 \mathrm{C} 40$

\section{Copyrights}

Copyright for this article is retained by the author(s), with first publication rights granted to the journal.

This is an open-access article distributed under the terms and conditions of the Creative Commons Attribution license (http://creativecommons.org/licenses/by/4.0/). 